\title{
Organizational loyalty as a characteristic of management quality for an energy company
}

\author{
$T D$ Syanevets* and $T V$ Sudakova \\ Omsk State University, 644077, 11 Neftezavodskaya Str., Omsk, Russia
}

\begin{abstract}
Globalization leads to the diminishing of national economic systems boundaries, standartization of production processes and companies management, thus it is becoming more difficult to form competitive advantages. Research has shown that company's competitiveness and its reputation depend on the management quality which is influenced by many factors including level of personnel loyalty. The problem concerning personnel loyalty is common for most Russian energy companies, the management stuff of which believe that employees should work efficiently as they get paid for it. Research shows that there are several problems in this field, namely: lack of effective communications between management stuff and employees, lack of workers interest in the results, low motivation for goals achievement, low-innovative behavior and so on. Managers consider these problems when it is too late and company faces bankruptcy and there is no time to alter the situation. Competencies in managing personnel loyalty defines important component of management quality - goodwill. Goodwill is a number of business elements and personal characteristics of workers, which stimulate clients to continue use of products and services of particular company and bring additional profit.
\end{abstract}

\section{Introduction}

Quality of management system is a set of features of a system, which define a company's ability to achieve success in socio-economic activity [1].

Quality of management system can be expressed using the following characteristics:

A) Socio-economic - image and company's mark, its place in world or national ratings, price strategy, economy;

B) Organizational - reliability, organization, adaptability, level of integration and differentiation of management, level of decentralization and diversification;

C) Social and psychological - communicativeness, corporativity, culture level, favorable sociopsychological climate, compatibility of workers, optimal style of management, ratio of formal and non-formal structures, ethics of management behavior, workers professionalism;

D) Technological - innovation, level of technology, technical armament.

In the conditions of market instability and innovation development a company cannot achieve success without personnel taking part in company's management, which is called "work core". Research has shown that working motivation is under serious test. Traditional methods of entrepreneurship in this place are aimed at costs reduction and workers' dismissal that does not improve workers' motivation, as well as formation and maintaining their social capital as a part of management quality.

Basis of modern social capital of Russian company comprises organizational values, norms, relations of trust and mutual help, social contacts and net. Unfortunately, during market transition traditional work values for Russian people such as mutual help, support, partnership, team spirit have moved to drastic degradation of relationship between management and workers, between different members in company. In this course personnel managers and line managers state the necessity to manage personnel loyalty.

Traditionally loyalty in Russian companies was kept by benefits package, career development and favorable socio-psychological climate, but in economic crisis conditions benefits package has lessened, career development is no longer available due to the economic growth decrease, high competitiveness made workers relations worse. So the question arises: how to manage personnel loyalty in these difficult conditions?

Firstly we define the meaning of the loyalty management. According to Ozhegov S.I., "loyalty is keeping formal in the limits of legality in the limits of favorable and neutral relationship to somebody or something"

According to Poteryahin A.L. "organizational loyalty is the positive attitude of personnel to company's management, which supposes emotional and rational evaluation and aspiration to maximum result of working activity in this organization" [2].

*orresponding author: omtibonn@gmail.com 
There are different definitions for loyalty, but most of them reduce to the following: loyalty is a working behavior of a certain kind, that can be characterized by law-abidingness and reliability, which is the basis for commitment to company's values and goals.

Thus, loyalty can be defined by two factors: lawabidingness and favorable attitude to somebody or something. This duality leads to plurality of loyalty forms, various levels of its expression and detachment of various kinds of loyalty to various managerial objects of a company. For instance, formation of loyalty to the fabricated product due to its usefulness for people, and/or loyalty to company's head as a professional or leader.

Thus, different forms and levels of loyalty are derived.

Research conducted by Grinberg G., Bairon R., Poteryahin A.L., Bazarov T.U., Eremin B.L., Meyer J.P., Allen N.J., Smith C.A., Lutens F., Mercunio [3-10] allows one to distinguish three levels of loyalty, namely:

1. Positive emotional relation to the object of loyalty (emotional form of loyalty). It is based on worker's need for socialization and safety, that allows forming friendly relationship, feeling of commitment;

2. Positive rational attitude towards object and one's involvement in it (pragmatic form of loyalty). This form in management includes evaluation of individual social benefits (comfortable working conditions, allowance, supplements, insurance and so on) and mutual benefits (gym, canteen, medical aid station and so on). Worker evaluates costs of losing these benefits when leaving company;

3. Readiness to make certain actions in favor of the loyalty object (normative form of loyalty). As a rule, this form of loyalty consists in executive discipline, maintaining the contract conditions and corporate norms.

In management practice the importance is not only in forms of loyalty as they interfere within each other but in the level of their expression.

Research on the strength of loyalty has led scientists to outlining levels of loyalty, but their number and content differ. Traditionally, O'Mally M.N. outlines three loyalty levels: content with work, involvement and commitment [3]. Russian researchers Voronin M. and Markova N. increased the number of loyalty levels to four, thus creating a loyalty pyramid, which included content, involvement, commitment and happiness. Authors believe that company should conquer workers' hearts, as their relation to company itself and its product influences the customer relation [4]. Most popular model was created by Solomanidina T.O., it includes five loyalty levels in accordance with the level of personnel personality development and the level of motivation towards achievement of the company goals: imitation loyalty, potential loyalty, motivated loyalty, standard accepted loyalty, loyalty on the level of values and beliefs that moves to commitment [5, p. 509-524].

Harskiy K.V., the well-known Russian consultant, makes accent on the levels of loyalty disintegration (in terms of Kohen M.): open disloyalty, hidden disloyalty, normative level, formal attributes loyalty, actions loyalty, loyalty on belief level and identification with company [6]. The French researcher Kohen M. outlines levels and stages of worker's and company's disintegration and also defects in personnel management and HR policy [6]. Undoubtedly, in one company there are workers with positive and negative (disintegrative) loyalty, that make line managers and HR managers to use different methods in their work.

Each researcher while outlining loyalty levels uses certain criteria, which characterize the observed worker's behavior or traits that show their attitude towards company. Analysis of notions used for loyalty description (trust, involvement, reliability, fidelity, commitment, etc) and consideration of levels of hierarchy of loyalty objects, towards which emotional and rational attitude are formed (work content, work conditions and relations with management, management quality) lead us towards creation of authors research. It is based on loyalty levels consideration in accordance with experience and research on socio-working relations (Figure 1):

\begin{tabular}{|l|}
\hline 5. Commitment to company \\
\hline $\begin{array}{l}\text { 4. Self-organization based on consciousness and respon- } \\
\text { sibility }\end{array}$ \\
\hline 3. Involvement in socio-working processes \\
\hline 2. Trust to management \\
\hline 1. Satisfaction with work \\
\hline Personnel loyalty levels towards organization \\
\hline
\end{tabular}

Fig. 1. Organizational loyalty levels.

Further we give characteristics for each personnel loyalty level.

Satisfaction with work is measured by evaluation of correctness of company's obligations given to worker: do the worker's duties comply with his position in company, are wages paid in time and in full, whether the work is evaluated to the merits. On this level of loyalty worker follows certain rules and formally carries his duties.

Trust to management is achieved when management does what it manifests. Management is capable of setting goals and achieving them. This position forms workers' confidence in managerial professionalism and their future. They listen to instructions and advices and it raises their responsibility for work results. This results in neutral attitude.

Involvement of personnel into company's workflow characterizes the level to which a worker associates himself with company, shares its goals, and sees opportunities for future development. This loyalty level has emotional tint as workers realize mutual interest, show attitude towards work and are ready to discuss means to achieve aims. Working discipline and self motivation rise.

Self-organization based on consciousness and responsibility characterizes the beginning of mutual identification among self values and values of organization. Individual realizes his interest not only in the current work but also his strategic aims, as a result one is ready to take responsibility for their achievements. 
Commitment to company characterizes personnel commitment to the mutual work. This is deep belief in the sense of company's existence sharing its values. Worker identifies his aims and values with aims and values of company, adjusts working behavior to mutual aims, feels emotional and rational commitment to that is happening in the company.

\section{Methods}

Investigations of organizational behavior performed by Bazarov T.U., Eremin B.L., Oksinoid K.E. [1,9] show that changes in management quality lead to the change in company's values and personnel loyalty level for various company levels. The authors develop two hypotheses for empirical research:

1). Personnel loyalty is formed while moving from one level to the higher one;

2). Organizational loyalty and "trust to management" in Omsk companies are at the middle level.

The research was conducted in 45 Omsk companies. The choice of companies was random. The used methods were observation and interview of management and workers (from $5 \%$ to $10 \%$ of all personnel). Method for organizational personnel loyalty research is based on registration of attributes of organizational loyalty, such as working conditions, compliance to labor legislation, head professionalism and other attributes that can be observed. Opinions of management and workers regarding more complicated things for observance, such as "I defend the company outside its boundaries", "I am ready to take responsibility for mutual work results" and others, we gathered through interviews, that allowed measuring severity level of various organizational loyalty levels. The comparison of management opinions with workers' ones makes it possible to evaluate level of understanding and recognition of organizational values.

\section{Results and discussion}

Empirical research shows that in energy companies the level of organizational loyalty is rather high and is located between "involvement in socio-working processes" and "self-organization based on consciousness and responsibility". It heavily depends on the scale and economic position of the company and it is different for various managerial levels. Companies involved in hydrocarbon production and companies that generate electricity have high or above average loyalty level. That coincides with "involvement in socioworking processes" and "self-organization based on consciousness and responsibility". Though 63\% of personnel show loyalty level that can be described as "satisfaction with work", moreover, satisfaction depends on the wages. Middle-level managers see their loyalty level as "involvement in socio-working processes"; only $71 \%$ of higher level management is ready to say that their loyalty level is at the level "self-organization based on consciousness and responsibility". Managers tend to be cynical about the companies they work in, and consider their workplace as a means for self prosperity, they are ready to obey rules and show responsible behavior but for the higher salary.

Companies that work in the field of hydrocarbon transportation and use, energy supply, show the same level of organizational loyalty as "management trust" and "involvement in socio-working processes". It is important to mention that economic position of the company has the most influence, the more stable and profitable is it, the higher level of loyalty is achieved. Moreover, investigation has resulted in the following conclusion: formation of organizational loyalty does not come from bottom to top on the levels of loyalty, but it is formed separately for each component on each level. Thus, for instance, workers can be unsatisfied with career development perspectives but can trust managers in decision making and share the company mission while approving the company strategy. This shows high professional levels of personnel and their interest in companies' development.

The Table showing loyalty level and quality management connection was obtained based on research (Table 2).

\section{Conclusions}

Thus, in Russia the workers' attitude towards company

Table 2. Management quality and organizational values on different personnel loyalty levels.

\begin{tabular}{|l|l|l|}
\hline \multicolumn{1}{|c|}{ Personnel loyalty levels } & \multicolumn{1}{|c|}{ Quality of management } & \multicolumn{1}{c|}{$\begin{array}{c}\text { Prevailing organizational } \\
\text { values }\end{array}$} \\
\hline 1. Satisfaction with work & $\begin{array}{l}\text { Working conditions and work } \\
\text { content }\end{array}$ & $\begin{array}{l}\text { Law-abidingness, discipline, duty, } \\
\text { responsibility }\end{array}$ \\
\hline 2. Trust in management & Relations justice & $\begin{array}{l}\text { Aim, professionalism, improvement, } \\
\text { social responsibility }\end{array}$ \\
\hline $\begin{array}{l}\text { 3. Involvement into socio-labor } \\
\text { processes }\end{array}$ & $\begin{array}{l}\text { Mutual interest, mobility, initiative, } \\
\text { customer focus }\end{array}$ \\
\hline $\begin{array}{l}\text { 4.Self-organization based on } \\
\text { consciousness and responsibility }\end{array}$ & Horizontal partnership & $\begin{array}{l}\text { Trust, self control and responsibility, } \\
\text { productivity, innovation }\end{array}$ \\
\hline $\begin{array}{l}\text { 5. Commitment to company } \\
\text { Equality, freedom and responsibility, } \\
\text { quality and transparency of } \\
\text { management }\end{array}$ \\
\hline
\end{tabular}


they are working in is an important part of management quality, which appears on the level of organizational loyalty. These facts are also confirmed in the works of Rajendra S, Sisodia D, Wolfe and Jagdish N. Sheth. [5]

During research the first hypothesis "personnel loyalty is formed gradually, moving from lower level to higher" was not proven, as in fact loyalty is formed towards different aspects of company's work. If the worker is not satisfied with work conditions or career development possibilities, he can be satisfied with management actions or participating in projects, supporting company's reputation. The second hypothesis „organizational loyalty in Omsk companies is below middle level, thus being on the "management trust level" was not proven as well. Complex attitude towards loyalty formation leads to the fact that organizational loyalty in Russian companies maintains high level.

\section{References}

1. A.L. Poteryahin, Organizational personnel loyalty: definitions and notions (http://labipt.com)

2. K.E. Oksinoid, Loyalty of personnel (2018) (http://www.elitarium.ru/lojalnost_predannost_pers onala)

3. M.N. O'Malley, Creating Commitment: How to Attract and Retain Talented Employees, 325 (2000)

4. T.D. Sinyavets, Problematic aspects of management effectiveness analysis methodology, Herald of Omsk University, 4, 26-35 (2012)

5. S. Rajendra, D.V. Sisodia, N. Wolfe, N.S. Jagdish, Firms of Endearment How World-Class Companies Profit from Passion and Purpose, Pearson Education, Inc Wharton School Publishing, 1, 336 (2007)

6. K. Harskiy, Trustworthiness and loyalty of personnel, 289 (2003)

7. T.U. Bazarov, B.L. Eremin, Personnel management, $560(2002)$

8. C. Brown, C. Gilroy, A. Kohen, The Effect of the Minimum Wage on Employment and Unemployment, Journal of Economic Literature, 487-528 (1982)

9. J.D. Greenberg, R.A. Baron, Behavior in Organizations: Understanding and Managing the Human Side of Work, 691 (2003)

10. F. Lutens, Organizational behavior, 265 (1999)

11. J.P. Meyer, Building Commitment in an Era of Change (2000)

12. J.P. Meyer, N.J. Allen, C.A. Smith, Commitment to organizations and occupations: extension and test of a three-component conceptualization, Journal of Applied Psychology, 78(4), 538-551 (1993)

13. Z.A. Mercurio, Affective commitment as a core essence of organizational commitment: an integrative literature review, Human Resource Development Review, 14(4),389-414 (2015)

14. T.O. Solomandina, Organizational company culture, 624 (2011)

15. M. Voronin, N. Markova, Winning the Hearts: how to appeal to personnel (2017) (https://www.cfin.ru/management/people/motivatio n/Winning_Hearts.shtml) 